\title{
Diuretic activity of ethanolic extract of whole plant of Sphaeranthus indicus linn in albino rats
}

\author{
Preeja K. Sundaresan $^{1}$ *, Sonish S. Prabhakaran ${ }^{1}$, Dhanya S. Palappallil ${ }^{2}$, \\ Dharmarajan Chellappan $^{3}$
}

\begin{abstract}
${ }^{1}$ Department of Pharmacology, Government Medical College, Thiruvananthapuram, Kerala 695011, India

${ }^{2}$ Department of Pharmacology, Government TD Medical College, Alappuzha, Kerala 688005, India

${ }^{3}$ Department of Paediatrics, Junior Consultant, GH

Neyyattinkara,

Thiruvananthapuram, Kerala, India
\end{abstract}

Received: 18 December 2016 Accepted: 24 December 2016

*Correspondence to:

Dr. Preeja K. S.,

Email:

drpreeja79@rediffmail.com

Copyright: (C) the author(s), publisher and licensee Medip Academy. This is an openaccess article distributed under the terms of the Creative Commons Attribution NonCommercial License, which permits unrestricted noncommercial use, distribution, and reproduction in any medium, provided the original work is properly cited.

\begin{abstract}
Background: Sphaeranthus indicus Linn (S. indicus Linn) is a medicinal plant widely used in Indian traditional system of medicine for treating various ailments. The aim of the study was to evaluate diuretic activity by Lipschitz method in albino rats.

Methods: Thirty albino rats were grouped into five groups and each contained six rats. Group I (control group) received $25 \mathrm{ml} / \mathrm{kg}$ each of $0.9 \%$ sodium chloride orally. Group II (standard) received Hydrochlorothiazide $25 \mathrm{mg} / \mathrm{kg}$ orally dissolved in isotonic normal saline. Groups III, IV and V received ethanolic extracts of $S$. indicus Linn in doses $100 \mathrm{mg} / \mathrm{kg}, 200 \mathrm{mg} / \mathrm{kg}$ and $300 \mathrm{mg} / \mathrm{kg}$ respectively dissolved in isotonic saline orally. The mice were put in metabolic cages and urine samples were collected for all the groups up to 24 hours after dosing. Urine was analysed for volume, urinary excretion ratio, diuretic activity, sodium and potassium composition electrolytes. Data was analysed using SPSS version 16 for windows.

Results: Single dose administration of S. indicus in doses of 100, 200 and 300 $\mathrm{mg} / \mathrm{Kg}$ as compared to Hydrochlorothiazide $(25 \mathrm{mg} / \mathrm{kg}$ )have significantly ( $\mathrm{p}<0.001$, ANOVA) increased total urine output along with an increase in concentration of sodium and potassium. S. indicus Linn $300 \mathrm{mg} / \mathrm{Kg}$ produced greater diuretic activity, which is comparable to the effect of standard.

Conclusions: The extract treated rats showed a dose dependent increase in urine volume. Maximum diuretic and kaliuretic activity were observed at the dose of $300 \mathrm{mg} / \mathrm{kg}$ of the extract. The present study supports and confirms the basis for folklore use of $S$. indicus Linn as a diuretic agent.
\end{abstract}

Keywords: Diuretic activity, Ethanolic extract, Sphaeranthus indicus Linn, Whole plant

\section{INTRODUCTION}

Diuretics are agents that increase the rate of urine flow and adjust the volume and composition of body fluids in several clinical situations such as acute and chronic renal failure, cirrhosis of liver and hypercalciuria. Druginduced diuresis is useful in many life-threatening disease conditions such as congestive heart failure (CHF), hypertension, nephritis and pregnancy toxemia. ${ }^{1}$ Most diuretic drugs have been associated with numerous adverse effects such as electrolyte imbalance, development of new-onset diabetes, metabolic alterations, activation of the renin-angiotensin and neuroendocrine systems and impairment of sexual function. $^{2}$ In this scenario, the need for novel diuretics such as plant-based substances, which are considered to 
be relatively safe and possessing lower potential for adverse effects, is advocated.

India has been endowed with a very rich flora owing to the extreme variations in climate and geographical conditions prevalent in the country. Loss of traditional knowledge is recognized as of great global concern in the present century. ${ }^{3}$ The need for documentation of traditional knowledge on medicinal plants with scientific studies are necessary to develop more trust and faith towards this potential knowledge. A mechanism with high potential for protection of traditional knowledge is its documentation in databases and registers. ${ }^{4}$ The present study is significant in this direction to capture evidence on diuretic activity of Sphaeranthus indicus Linn.

\section{Plant description}

Sphaeranthus indicus Linn is a multi-branched aromatic herb 1-2 feet in height, distributed commonly in plains all over India and up to an altitude of 50 feet in hills. ${ }^{5} \mathrm{~S}$. indicus Linn is known in different names in different Indian languages as Kamadarus, Mudmudiya, Gorakhmundi, Atookamanni, Mundi, Buikadam, Gorakhmundi, Adakkamaniyan, Kottakarthai, Bodasaramu. ${ }^{6}$ In Ayurvedic system of medicine, the whole herb is used in insanity, anaemia, piles, asthma, leukoderma, indigestion, bronchitis, spleen diseases, elephantiasis dysentery, vomiting and urinary discharges. ${ }^{7}$ The whole herb is used in Ayurvedic preparations to treat mental disorders and epilepsy. ${ }^{8-10}$ Hot water extract of the herb is used as an anthelminitic, fish poison, diuretic, and as an aphrodisiac. ${ }^{11-13}$ Flowers are used in conjunctivitis. ${ }^{12}$ The external application of a paste of this herb is useful in treating pruritus and edema, gout, arthritis, filariasis and cervical adenopathy. ${ }^{14}$ The plant is traditionally used for diarrhea. ${ }^{15}$

Scientific studies had revealed its anxiolytic activity, neuroleptic activity, sedative effect, immunomodulatory activity, antioxidant activity, anti-inflammatory activity, analgesic activity and antipyretic activity, mast cell stabilizing action, hepatoprotective activity, antibacterial, antifungal activity, antiviral activity and anti-amoebic activity, bronchodilatory effect, antihyperlipidemic effect, and anticancer activity. ${ }^{16-28}$ The major constituents of $S$. indicus Linn include methyl chavicol, $\delta$-cadinene, $\alpha$ ionone, para-methoxycinnamaldehyde, $\alpha$-terpinene, citral, geraniol, geranyl acetate, $\beta$-ionone, oscimene, eugenol, sphaeranthene, sphaeranthol, estragole, and indicusene. $^{29,30}$

S. indicus Linn is used traditionally used as a diuretic but scientifically was not evaluated as a diuretic agent. The main aim of the present study was to evaluate diuretic activity of whole plant ethanolic extract of $S$. indicus Linn by Modified Lipschitz Test in hydrated albino rats.

\section{METHODS}

Fresh whole plant of $S$. indicus Linn were procured from an organic farm and were authenticated by the Pharmacognosy unit, Ayurveda Research Institute, Poojappura, Thiruvananthapuram, South Kerala, India.

The whole plants were washed thoroughly with water, shade dried, and powdered coarsely. It was then repeatedly macerated with $95 \%$ ethanol in a percolator. ${ }^{31}$ The combined filtrate was subjected to evaporation in order to dry it under reduced pressure at $40-50^{\circ} \mathrm{C}$. The resulting crude ethanol extract was stored at $10-15^{\circ} \mathrm{C}$. Phytochemical evaluation for the extract was performed using standard procedures. ${ }^{32}$

Wistar strain albino rats (100-200 grams) of male sex were used for diuretic study. The animals were housed under standard laboratory conditions in the animal house of Government Medical College, Thiruvananthapuram. The animals were fed standard pellet diet, maintained on a natural light and dark cycle and had free access to water and food. They were acclimatized to laboratory conditions before the study. The experimental protocols were approved by the Institutional Animal Ethics Committee and ethical guidelines were followed throughout the study. All rats were housed in metallic cages 6 in each and temperature maintained at $22^{\circ} \mathrm{C} \pm 2^{\circ} \mathrm{C}$. Hydride tablet (Hydrochlorothiazide- $25 \mathrm{mg}$ ) of Micro Labs was used as standard for studying diuretic activity.

The acute toxicity of plant $S$. indicus Linn was determined by using albino mice of either sex (16-20 g), maintained under standard husbandry conditions. The animals were fasted for $3 \mathrm{hrs}$ prior to the experiment and the extract was administered as single dose and observed for the mortality up to 48 hours study period (short term toxicity). Based on the short term toxicity profile, the consecutive dose of the extract was determined as per Organisation for Economic Co-operation and Development guidelines No. 420. ${ }^{33,34}$ The maximum dose tested $(2000 \mathrm{mg} / \mathrm{kg})$ for LD50. From the LD50, doses like1/15th, 1/10th and 1/5th were selected and considered as low, medium and high dose i.e. $100 \mathrm{mg} / \mathrm{kg}, 200$ $\mathrm{mg} / \mathrm{kg}, 300 \mathrm{mg} / \mathrm{kg}$ respectively to carry out this study.

Diuretic action of $S$. indicus was investigated in male albino rats employing the method of Lipschitz et al. ${ }^{35,36}$ Thirty albino rats were grouped into five groups each containing six. They were deprived of food and water 18 hours prior to the experiment. Control group received $25 \mathrm{ml} / \mathrm{kg}$ each of $0.9 \%$ sodium chloride orally. Standard group was given Hydrochlorothiazide $25 \mathrm{mg} / \mathrm{kg}$ orally dissolved in isotonic normal saline. The rats in the other three groups were given the extract dissolved in isotonic saline orally in the doses $100 \mathrm{mg} / \mathrm{kg}, 200 \mathrm{mg} / \mathrm{kg}$ and $300 \mathrm{mg} / \mathrm{kg}$ each. Metabolic cages made of stainless steel were used to collect the urine. Amount of urine collected at the end of 24 hours was noted. Urinary excretion and diuretic activity were calculated for all groups and 
compared. The electrolyte composition (sodium and potassium) of collected urine for different groups were analyzed by Ion Selective Electrode method as described by the user instruction manual of the biochemical kits (Roche, Roche Diagnostics Pvt. Ltd., Gurgaon, Haryana, India) and the results compared statistically.

Experimental results were expressed as mean \pm standard error of mean. Statistical analysis was performed with one-way ANOVA using SPSS for Windows, Version16.0 (SPSS Inc., Chicago, USA).

\section{RESULTS}

Sphaeranthus indicus Linn was subjected to qualitative phytochemical tests to identify the phytoconstituents and it revealed the presence of carbohydrates, alkaloids, sterols, phenolic compounds, tannins, flavonoids and resins. In acute toxicity study, all the animals survived even after 14 days. This shows that the extract was found to be safe up to the maximum dose level tested (2000 $\mathrm{mg} / \mathrm{kg}$ ). No major behavioural changes were observed during this period of study.

As shown in Table 1, S. indicus Linn has showed significant diuretic activity by increasing urinary output. As shown in Table 2 there was increased excretion of sodium, potassium levels when compared with control. The effect of $S$. indicus Linn was found to be dose dependent, i.e., among the three doses studied, higher doses produced more effect as depicted in Figures 1 and 2. A comparison was made with the standard diuretic drug Hydrochlorothiazide. The diuretic effect observed after treatment with $S$. indicus Linn was found to be significant in terms of urinary output, sodium and potassium concentrations. It was found that the extract possessed good kaliuretic action. Sodium excretion was also increased with increasing doses of the extract. Maximum diuretic and kaliuretic activity were observed at the dose of $300 \mathrm{mg} / \mathrm{kg}$ of the extract as shown in Figure 1.

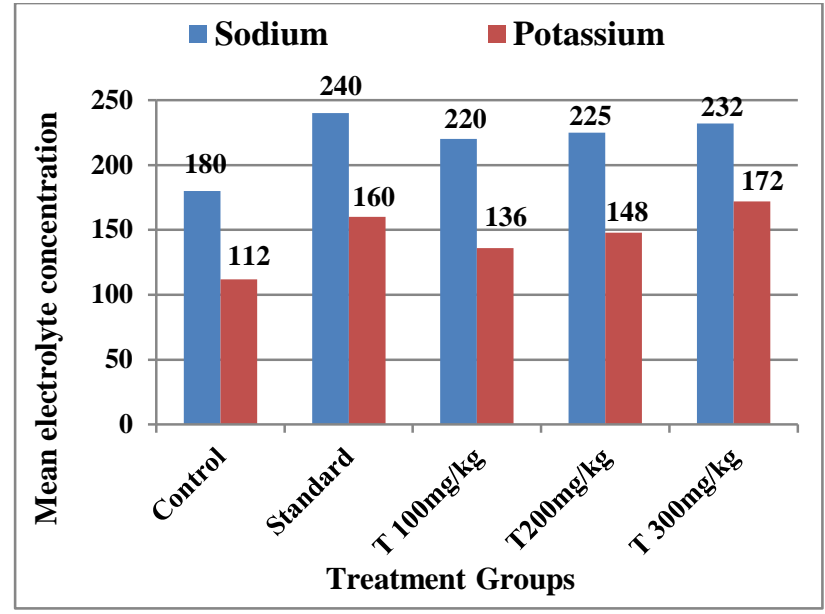

Control-Normal Saline, Standard-Hydrochlorothiazide

Figure 1: Diuretic activity (electrolyte concentration) of Ethanolic extracts of Sphaeranthus indicus.

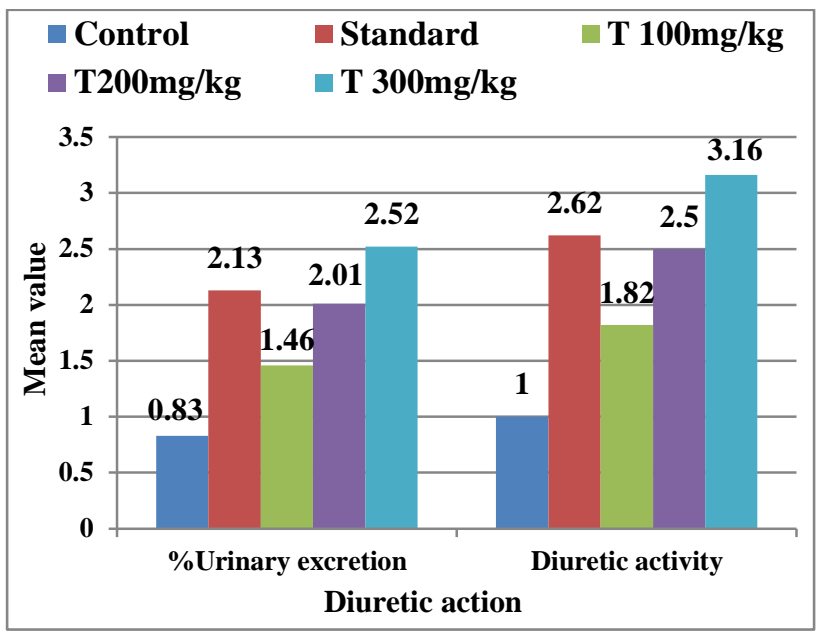

Control-Normal Saline, Standard-Hydrochlorothiazide

Figure 2: Effect of ethanolic extract of Sphaeranthus indicus Linn on urinary excretion and diuretic activity.

Table 1: Effects of oral Ethanolic extract of Sphaeranthus indicus Linn on urine output.

\begin{tabular}{|lllll|}
\hline Treatment group & Dose $($ oral) & Urine output $(\mathrm{ml})$ & \%Urine excretion $(\mathrm{ml})$ & Diuretic activity \\
\hline Control & $25 \mathrm{ml} / \mathrm{kg}$ & $12.00 \pm 1.51$ & $00.83 \pm 0.26$ & $1.00 \pm 0.23$ \\
\hline Standard & $25 \mathrm{mg} / \mathrm{Kg}$ & $32.00 \pm 3.09$ & $2.13 \pm 0.58$ & $2.62 \pm 0.37$ \\
\hline Test 1 & $100 \mathrm{mg} / \mathrm{kg}$ & $22.10 \pm 1.83^{*}$ & $1.46 \pm 0.51^{*}$ & $1.82 \pm 0.52^{*}$ \\
\hline Test 2 & $200 \mathrm{mg} / \mathrm{kg}$ & $30.00 \pm 1.81^{*}$ & $2.01 \pm 0.33^{*}$ & $2.50 \pm 0.31^{*}$ \\
\hline Test 3 & $300 \mathrm{mg} / \mathrm{kg}$ & $38.00 \pm 1.70^{*}$ & $2.52 \pm 0.39^{*}$ & $3.16 \pm 0.12^{*}$ \\
\hline
\end{tabular}

Values are Mean \pm Standard Deviation. The data were analysed by one-way ANOVA.

*p value $<0.001$, when compared with control and treated groups.

Control-Normal Saline, Standard-Hydrochlorothiazide

\section{DISCUSSION}

Modern medicine is making rapid strides day by day. Still it has not been completely successful in the prevention and cure of all human ailments. Many valuable drugs of today came into the vogue through the study of indigenous remedies. Useful compounds such as digitonins, papain, morphine, codeine exert pharmacological activity. Phytopharmaceuticals are gaining more importance and will open up new vistas in drug development. 
Table 2: Effects of oral Ethanolic extract of Sphaeranthus indicus on electrolyte excretion.

\begin{tabular}{|llll|}
\hline Treatment Group & Dose $($ Oral $)$ & Na $+(\mathrm{mEq} / \mathrm{l})$ & $\mathrm{K}+(\mathrm{mEq} / \mathrm{L})$ \\
\hline Control & $25 \mathrm{ml} / \mathrm{kg}$ & $180 \pm 7.50$ & $112 \pm 3.41$ \\
\hline Standard & $25 \mathrm{mg} / \mathrm{Kg}$ & $240 \pm 5.47$ & $160 \pm 3.46$ \\
\hline Test 1 & $100 \mathrm{mg} / \mathrm{kg}$ & $220 \pm 3.46^{*}$ & $136 \pm 2.89^{*}$ \\
\hline Test 2 & $200 \mathrm{mg} / \mathrm{kg}$ & $225 \pm 3.74^{*}$ & $148 \pm 2.89^{*}$ \\
\hline Test 3 & $300 \mathrm{mg} / \mathrm{kg}$ & $232 \pm 6.90^{*}$ & $172 \pm 2.36^{*}$ \\
\hline
\end{tabular}

Values are Mean \pm Standard Deviation. The data were analysed by one-way ANOVA.

*p-value $<0.001$, when compared with control and treated groups.

Control-Normal Saline, Standard-Hydrochlorothiazide

Herbal drugs should be exploited to their zenith so that they are cost effective alternatives or they can provide crude drugs for the final synthesis of active compounds. It is therefore necessary to acquire and preserve the traditional system of medicine by proper documentation and identification of herbal remedies. Though there is a general belief that herbal remedies are totally harmless, safety of herbal drugs should be proven beyond any doubt for human use. There is a revival of interest in herbal medicines because basic molecular and active structures for synthetic fields are provided by rich natural sources. The relatively lower incidence of adverse reactions to plant preparations compared to modern conventional pharmaceuticals coupled with their reduced cost is encouraging both the consuming public and national health care institutions to consider plant medicines as alternatives to synthetic drugs.

S. indicus can be used for the treatment of various disease conditions. Studies done on S. indicus justify the therapeutic application of this plant in indigenous system of medicine augmenting its therapeutic value. The diuretic property of ethanolic extract of $S$. indicus was evaluated in the present study. It was proved to be a very safe drug since it did not produce any mortality in animal study when doses up to $2000 \mathrm{mg} / \mathrm{kg}$ were given orally. ${ }^{37}$ Diuretics are drugs which can increase urine output and bring about changes in electrolyte composition of the body. They have their benefit in a good number of clinical conditions. Diuretics relieve pulmonary congestion and peripheral edema, so these agents are useful by reducing the volume overload and offer symptomatic relief of orthopnoea and paroxysmal nocturnal dyspnoea. They decrease plasma volume and subsequently venous return to the heart. This decreases cardiac work, oxygen demand and plasma volume thus decreasing blood pressure.

The control of plasma sodium is important in the regulation of blood volume and pressure. The control of plasma potassium is required to maintain proper function of cardiac and skeletal muscle. considered to be 'good' by Gujral et al. ${ }^{38}$ Diuretic activity is considered to be good if $>1.5$, moderate if 1 1.5 , little if $0.72-1$ and nil if $<0.72$. On analysing the electrolyte composition of urine, it was seen that it also possess significant kaliuretic property. Both these properties can be utilized in a variety of disease conditions. Diuretics can be used along with massive blood transfusions to prevent volume overload. In this situation both diuretic and kaliuretic properties of $S$. indicus can be utilized since massive blood transfusion can lead to hyperkalemia due to release of potassium from stored red blood cells. It is a promising adjuvant drug along with antihypertensive which increase potassium levels like Angiotensin converting enzyme inhibitors and Angiotensin receptor antagonists in patients not responding when used alone.

In the present study whole plant ethanolic extract showed elevated levels of potassium in urine which may increase the risk of hypokalemia. However, it should be used with caution when other diuretics are also given concurrently since additive hypokalemia can occur. Active phytoprinciples such as flavonoids, saponins and terpenoids are known to be responsible for diuretic activity. ${ }^{39,40}$ The presence of these active principles in $S$. indicus may be responsible for its diuretic activity.

\section{CONCLUSION}

The results showed that single dose administration of whole plant ethanolic extract of $S$. indicus Linn in doses of 100,200 and $300 \mathrm{mg} / \mathrm{Kg}$ have increased the urinary output along with an increase in concentration of sodium and potassium ions in urine. S. indicus Linn $300 \mathrm{mg} / \mathrm{Kg}$ produced a greater diuretic activity, which is comparable to that of Hydrochlorothiazide $25 \mathrm{mg} / \mathrm{kg}$. The present study supports and justifies the rationale behind the folklore use of whole plant of Sphaeranthus indicus Linn for diuretic activity. However, further systematic photochemical studies are necessary to elucidate the probable structure activity relationship of biomolecules.

The present study shows that the ethanolic extract of $S$. indicus has maximum diuresis at $300 \mathrm{mg} / \mathrm{kg}$. The diuretic activity of $S$. indicus in three doses were 


\section{ACKNOWLEDGMENT}

The authors are very much grateful to Mr. Rajmohan, Associate Professor, Pharmacy College, Thiruvananthapuram, Kerala for support and proper guidance to carry out this experimental work.

Funding: No funding sources

Conflict of interest: None declared

Ethical approval: The experiment complied with the guidelines for animal experimentation of our laboratory and was approved by the Institutional Animal Ethics Committee (IAEC)

\section{REFERENCES}

1. Agunu A, Abdurahamn EM, Andrew GO, Muhammed Z. Diuretic activity of stem-bark extracts of Steganotaenia araliaceae hochst [Apiaceae]. J Ethnopharmacol. 2005;96:471-5.

2. Gupta S, Neyses L. Diuretic usage in heart failure: A continuing conundrum in 2005. Eur Heart J. 2005;26:644-9.

3. Ramirez CR. Ethnobotany and Loss of Traditional Knowledge in the 21st Century. Ethnobotany Research and Application. 2010;5:245-7.

4. Sudeesh M. Ethnobotanical plants used by Malayaraya tribes of Vannapuram village in Idukki, Kerala. Indian J Sci Res Technol. 2012;1:7-11.

5. Ramachandran S. Review on Sphaeranthus indicus Linn. (Kottaikkarantai). Pharmacogn Rev 2013;7:157-69.

6. Misra A, Kumar A. Studies on Ayurvedic drugs for the cure of urinary tract stones. J Indian Bot Soc. 2000;79:47-8.

7. Kirtikar KR, Basu BD, ICS. Indian medicinal plants. In: Blatter E, Caius JF, Mhaskar KS, editors. $2^{\text {nd }}$ ed. Allahabad, India: Lalit Mohan Basu; 1981;2:1346-8.

8. Nadkarni AK. Indian Materia Medica. $3^{\text {rd }}$ ed. Bombay: Popular Parkashan Private Ltd; 2007;1:1163.

9. Prajapati N, Purohit SS, Sharma AK, Kumare TA. $1^{\text {st }}$ ed. Jodhpur: Agrobios. Handbook of Medicinal plants: A complete source book; 2003:484.

10. Agarwal VS. New Delhi: Kalyani Publishers. Drug plants of India; 1997;2:656.

11. Paranjape P. Indian medicinal plants. In: Paranjape P, editor. Forgotten healer: A guide to Ayurvedic herbal medicine. Delhi: Chaukhamba Sanskrit Pratisthan; 2001:148-149.

12. Chopra RN, Nayar SL, Chopra IC. $1^{\text {st }}$ ed. New Delhi: National Institute of Science Communication; 1996. Glossary of Indian Medicinal Plants; p. 232.

13. Kapoor SL, Kapoor LD. Medicinal plant wealth of the Karimnagar district of Andhra pradesh. Bull Med Ethnobot Res. 1980;1:120-44.

14. Sahu TR. Less known uses of weeds as medicinal plants. Ancient Sci Life. 1984;3:245-9.

15. Girach RD, Aminuddin, Siddioui PA, Khan SA. Traditional plant remedies among the Kondh of district Dhenkanal (Orissa). Int $\mathrm{J}$ Pharmacog. 1994;32:274-83.

16. Ambavade SD, Mhetre NA, Tate VD, Bodhankar SL. Pharmacological evaluation of the extracts of Sphaeranthus indicus flowers on anxiolytic activity in mice. Indian J Pharmacol. 2006;38:254-9.

17. Mhetre NA, Ambavade SD, Bodhankar SL. Neuroleptic activity of extract of Sphaeranthus indicus in mice. Indian J Nat Prod. 2006;22:24-7.

18. Galani VJ, Patel BG. Psychotropic activity of Sphaeranthus indicus Linn. In experimental animals. Pharmacog Res. 2009;1:307-13.

19. Bafna AR, Mishra SH. Immunomodulatory activity of methanol extracts of flower heads of Sphaeranthus indicus Linn. Ars Pharmaceutica. 2004;45:281-91.

20. Shirwaikar A, Prabhu KS, Punitha IS. In vitro antioxidant studies of Sphaeranthus indicus (Linn) Indian J Exp Biol. 2006;44:993-6.

21. Tiwari BK, Khosa RL. Hepatoprotective and antioxidant effects of Sphaeranthus indicus against acetaminophen induced hepatotoxicity in rats. J Pharma Sci Res. 2009;1:26-30.

22. Nanda BK, Jena J, Rath B, Behera BR. Analgesic and Antipyretic activity of whole parts of Sphaeranthus indicus Linn. J Chem Pharma Res. 2009;1:207-12.

23. Mathew JE, Srinivasan KK, Dinakaran V, Joseph A. Mast cell stabilizing effects of Sphaeranthus indicus. J Ethnopharmacol. 2009;122:394-6.

24. Nayak SS, Maity TK, Maiti BC. Hepatoprotective activity of Sphaeranthus indicus Linn. Int J Green Pharm. 2007;1:32-6.

25. Lalla PM, Deshpande AR, Musaddip M, Shahare NH, Ukesh CS. Maharashtra: Amravati. Antimicrobial activity of Medicinal plant Sphaeranthus indicus. International conference on modern trends in plant sciences with special reference to the role of biodiversity in conservation; 2005:96.

26. Dhar ML, Dhar MM, Dhawan BN, Mehrotra BN, Ray C. Screening of Indian plants for biological activity. Part-I. Ind J Exp Biol. 1968;6:232-47.

27. Sarpate RV, Deore TK, Tupkari SV. Bronchodilatory effect of Sphaeranthus indicus Linn against allergen induced bronchospasm in guinea pigs. Pharmacog Mag. 2009;5:74-7.

28. Pande VV, Dubey S. Antihyperlipidemic activity of Sphaeranthus indicus on atherogenic diet induced hyperlipidemia in rats. Int $\mathrm{J}$ Green Pharm. 2009;3:159-61.

29. Baslas KK. The essential oil from Sphaeranthus indicus. Perfum Essent Oil Rec. 1959;50:765-8.

30. Lodha V. Chemical analysis of the essential oil of Sphaeranthus indicus: An Ayurvedic plant of India. Indian Perfumer. 2003;47:29-30.

31. Potduang B, Meeploy M, Giwanon R, Benmart Y, Kaewduang M, Supatanakul W. Biological activities of Asparagus recemosus. Afr J Tradit Complement Altern Med. 2008;5:230-7. 
32. Khandelwal KR. Practical Pharmacognosy: Techniques and Experiments.8th Ed. Pune: Nirali Prakashan. 2000;19:149-56.

33. OECD. Guidelines on Acute Oral Toxicity. Environmental Health and Safety Monograph Series on Testing and Adjustment. 2001:425.

34. Amresh G, Singh PN, Rao CV. Toxicological screening of traditional medicine Laghupatha (Cissampelos pareira) in experimental animals. J Ethnopharmacol. 2008;116:454-60.

35. Lipschitz WL, Hadidian Z, Kerpcsar A. Bioassay of diuretics. J Pharmacol Exp Ther. 1943;79:97-110.

36. Jayasree T, Kishore KK, Vinay M, Vasavi P, Chandrasekhar N, Manohar VS, et al. Evaluation of the diuretic effect of the chloroform extract of the Benincasa Hispida Rind (pericarp) extract in guinea pigs. J Clin Diagn Res. 2011;5:578-82.

37. Ghosh MN. Fundamentals of Experimental
Pharmacology. $2^{\text {nd }}$ Ed. Calcutta. Scientific book agency; 1984.

38. Gujaral ML, Saxena PN, Mishra SS. An experimental study of the comparative activity of indigenous diuretics. J Ind Med Agents. 1982;25:49-51.

39. Vetrichelvan T, Jagadeesan $M$, Palaniappan N, Sasikumar K. Diuretic and anti-inflammatory activities of Aervalanata in rats. Indian J Pharm Sci. 2000;62:300-2.

40. Beckette AH, Stenlake JB. Practical Pharmaceutical Chemistry Part-1, $1^{\text {st }}$ Ed. CBS Publishers and Distributors, New Delhi; 1997:197.

Cite this article as: Sundaresan PK, Prabhakaran SS, Palappallil DS, Chellappan D. Diuretic activity of ethanolic extract of whole plant of sphaeranthus indicus linn in albino rats. Int J Basic Clin Pharmacol 2017;6:265-70. 